\title{
Analisis Respon dan Faktor-Faktor yang Mempengaruhi Permintaan Beras Indonesia
}

\author{
Dudi Septiadia ${ }^{\mathrm{a}}$ Umbu Joka ${ }^{\mathrm{b}}$ \\ ${ }^{a}$ Fakultas Pertanian, Universitas Mataram, Kota Mataram - NTB, Indonesia. Email : dudi@ unram.ac.id \\ ${ }^{b}$ Fakultas Pertanian, Universitas Timor, Kefamenanu, TTU - NTT, Indonesia. Email : umbujoka@unimor.ac.id
}

\section{Article Info}

\section{Article history:}

Received 24 Mei 2019

Received in revised form 15 Juni 2019

Accepted 8 Juli 2019

DOI:

https://doi.org/10.32938/ag.v4i3.843

Keywords:

Beras

Permintaan

Analisis respon

Elastisitas

\section{Abstrak}

Penelitian ini bertujuan untuk 1) menganalisis faktor-faktor yang mempengaruhi permintaan beras Indonesia; dan 2) menganalisis respon permintaan beras dari faktor-faktor yang mempengaruhinya. Data pada penelitian ini menggunakan data time series periode 1988-2017. Analisis data menggunakan metode analisis regresi linear. Hasil penelitian menunjukan bahwa Permintaan beras Indonesia dipeng aruhi oleh harga beras eceran, pendapatan perkapita, jumlah penduduk, produksi beras dan lag permintaan beras Indonesia pada taraf $\alpha$ sebesar 5 persen dengan nilai $R$-Squared sebesar 91.3 persen. Berdasarkan analisis respon, variabel jumlah penduduk menjadi satu-satunya variabel bebas yang memiliki nilai elastisitas yang bersifat elastis $(E>1)$ baik dalam analisis jangka pendek maupun jangka panjang. Variabel harga beras eceran, pendapatan perkapita dan produksi beras memiliki nilai elastisitas yang bersifat inelastis $(\mathrm{E}<1)$ baik dalam analisa jangka pendek maupun jangka panjang.

\section{Pendahuluan}

Sektor pertanian merupakan salah satu sektor andalan dalam pembentuk PDB berdasarkan lapangan usaha. Sektor pertanian selalu masuk tiga besar sektor yang membentuk nilai PDB. Anriquez dan Stamoulis (2007) menilai bahwa sektor pertanian merupakan komponen penting khususnya dalam mendorong pertumbuhan perekonomian pedesaan di negara sedang berkembang. Sub sektor pertanian tanaman pangan merupakan sub sektor paling dominan di sektor pertanian. Salah satu komoditi tanaman pangan yang memiliki posisi penting dalam pembangunan pertanian adalah beras. Beras merupakan komodit strategis karena dapat mempengaruhi seluruh kebijakan dalam suatu negara yang menjadikan beras sebagai sumber pangan pokok (Rahmasuciana $d k k, 2015$ ) Beras memiliki peran yang sangat penting dalam ketahanan pangan.

Peran beras sebagai makanan pokok di Indonesia sampai saat ini sulit disubstitusikan dengan jenis makanan pokok yang lain. Bahkan ketergantungan terhadap komoditi beras seperti virus yang tak terkendali. Daerah-daerah di wilayah timur Indonesia yang dahulu menjadikan makanan pokok non-beras seperti jagung dan sagu seiring berjalannya waktu justru beralih mengkonsums beras sebagai makanan pokok. Tidak heran dewasa ini rasio konsumen Indonesia jika dibandingkan dengan jumlah penduduk terus mengalami peningkatan sehingga konsumsi beras Indonesia adalah konsumsi terbesar di dunia.

Peran beras sebagai komoditas perdagangan merupakan komoditas yang dibudidayakan di daerah-daerah pedesaan kemudian di perdagangkan dan di distribusikan ke seluruh daerah. Kawasan pedesaan merupakan sentra produksi beras sekaligus menjadi kawasan yang justru menjadi sarang kemiskinan. Ratarata kepemilikan lahan petani di Indonesia hanya mencapai $0.4 \mathrm{Ha} /$ kapita. Jumlah buruh tani yang tidak memiliki lahan masih jauh lebih banyak lagi. Di pedesaan begitu banyak pelaku yang sangat bergantung dengan komoditas ini. Begitu vital peran beras sebagai komoditas perdagangan, sehingga penting bagi lembaga terkait agar mengambil kebijakan pertanian yang tepat dan terukur dalam upayanya mensejahterakan petani dan mengentaskan kemiskinan.

Dari sisi permintaan, masyarakat di Indonesia memiliki ketergantungan yang begitu tinggi terhadap komoditas beras. Jumlah permintaan beras selalu meningkat, sementara jumlah produksi beras domestik nilainya berfluktuasi dan cenderung mengalami perlambatan. Gejala ini terjadi karena diduga luas areal panen padi yang terus berkurang karena beralih fungsi menjadi lahan industri dan perumahan. Implikasinya pemerintah seringkali dalam setiap tahun melalui Kementerian Perdagangan dan Perum Bulog melakukan kebijakan impor beras untuk menutupi kekurangannya. (Arifin, 1997). Padahal secara historis Indonesia pernah mencapai swasembada pengan, dimana faktor utama yang menjadikan Indonesia mampu mencapai swasembada beras pada tahun 1984 adalah dengan mengoptimalkan kebijakan peningkatan produktivitas melalui inovasi teknologi baru, investasi pembangunan prasarana irigasi, subsidi dan pengadaan sarana produksi, kebijakan harga dan tata-niaga beras, serta penyediaan kredit bersubsidi, (Rosegrant et al 1998).

Berdasarkan penjelasan tersebut, penting untuk dianalisis kembali perilaku konsumsi beras di Indonesia. Permintaan beras perlu dianalisis agar diperoleh hasil parameter estimasi yang akurat. Melalui informasi tersebut diharapkan bisa diformulasi kebijakan yang tepat agar gejolak perekonomian akibat tingginya permintaan beras disusul dengan meningkatnya harga bisa dideteksi dengan tepat. Berdasarkan uraian tersebut, penelitian ini bertujuan untuk: 1) menganalisis faktor-faktor yang mempengaruhi permintaan beras Indonesia. 2) menganalisis respon permintaan beras dari faktor-faktor yang mempengaruhinya.

\section{Metode}

Penelitian ini menggunakan jenis data runtut waktu (time series) dari periode tahun 1988 - 2017. Data dikumpulkan dari lembaga resmi negara seperti
Kementerian Pertanian, Kementerian Keuangan dan Badan Pusat Statistik. Data yang dikumpulkan diantaranya adalah data harga beras eceran domestik, pendapatan perkapita Indonesia, jumlah penduduk Indonesia, produksi beras Indonesia, lag permintaan beras Indonesia dan permintaan beras untuk konsumsi di Indonesia.

Data yang terkumpul selanjutnya dianalisis sesuai dengan hipotesis dalam penelitian. Hipotesis dalam penelitian ini di uji dengan menggunakan metode analisis regresi linier berganda. Alat analisis yang digunakan dalam penelitian ini adalah E-Views-9. Dengan demikian model penelitan dalam penelitian ini adalah sebagai berikut;

$P_{M B E R A S_{t}}=\beta_{0}+\beta_{1} H R B E_{t}+\beta_{2} P P P_{t}+\beta_{3} J P I_{t}+\beta_{4} P R O D B I_{t}+$ $\beta_{5} P M B E R A S_{t-1}+\varepsilon_{t} \ldots \ldots$ (1)

\section{Keterangan:}

PMBERAS $_{\mathrm{t}}=$ Permintaan beras untuk konsumsi di Indonesia pada periode $\mathrm{t}(\mathrm{Kg})$

$\mathrm{HRBE}_{\mathrm{t}} \quad=\quad$ Harga beras eceran pada periode $\mathrm{t}(\mathrm{Rp} / \mathrm{Kg})$

$\mathrm{PPP}_{\mathrm{t}} \quad=\quad$ Pendapatan perkapita penduduk Indonesia pada periode t $(\mathrm{Rp})$

$\mathrm{JPI}_{\mathrm{t}} \quad=\quad$ Jumlah penduduk Indonesia pada periode $\mathrm{t}$ (Jiwa)

PRODBI $_{\mathrm{t}} \quad=\quad$ Produksi beras Indonesia $(\mathrm{Kg})$

PBERAS $_{\mathrm{t}-1}=$ Lag Permintaan beras untuk konsumsi di Indonesia pada periode $\mathrm{t}(\mathrm{Kg})$ variabel lag permintaan beras Indonesia digunakan untuk kepentingan penggunan analisis respon elastisitas jangka panjang dalam penelitian

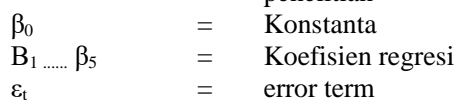

Tanda dam besaran parameter dugaan yang diharapkan adalah: $\beta_{2}, \beta_{3}, \beta_{4}$, $\beta_{5}>0$ dan $\beta_{1}<0$.

\subsection{Konsep Elastisitas}

Konsep elastisitas merupakan analisis yang digunakan untuk mendapatkan ukuran kuantitatif respon suatu fungsi terhadap faktor-faktor yang mempengaruhinya, sehingga bisa ditentukan seberapa peka variabel terikat akibat perubahan dari setiap variabel bebas yang mempengaruhinya.

$E-{ }_{S R}=\delta Y_{t} / \delta X_{t} * X_{t} / Y_{t} \ldots \ldots \ldots . .(2)$

$E-{ }_{L R}=E-_{S R} / 1-b \ldots \ldots \ldots \ldots \ldots$ (3)

Keterangan :

$\begin{array}{ll}E-{ }_{S R} & =\text { elastisitas jangka pendek } \\ E-{ }_{L R} & =\text { elastisitas jangka panjang } \\ \mathrm{B} & =\text { parameter dugaan variabel lag endogen } \\ \mathrm{X}_{\mathrm{t}} & =\text { rata-rata variabel eksogen } \\ \mathrm{Y}_{\mathrm{t}} & =\text { rata-rata variabel endogen }\end{array}$

\section{Hasil dan Pembahasan}

\subsection{Permintaan dan penawaran beras di Indonesia}

Permintaan terhadap beras domestik terdiri atas konsumsi rumah tangga dan konsumsi di luar rumah tangga yang meliputi untuk kebutuhan rumah makan, hotel, industri pengolahan, dan kebutuhan beras untuk cadangan rumah tangga. Komposisi penggunaan beras tersebut terdiri dari 85.46 persen konsumsi di dalam rumah, 1.48 persen restoran dan di luar rumah, dan 13.06 persen untuk industri pengolahan (Deptan, 2004). Melihat komposisi tersebut dapat dikatakan 
bahwa porsi penggunaan beras untuk konsumsi rumah tangga adalah yang terbesar dalam konsumsi beras nasional.

Perkembangan permintaan beras di Indonesia pada dua dekade terakhir mengalami trend yang terus meningkat. Berdasarkan gambar 1, Peningkatan tertinggi terjadi pada tahun 2004, dimana permintaan beras untuk konsumsi mencapai 30.621 juta ton. Tahun 2017, permintaan beras mencapai 33.473 juta ton dengan jumlah penduduk sebanyak 261 juta jiwa. Meningkatnya permintaan beras dipengaruhi oleh angka pertumbuhan penduduk yang jauh lebih besar pertumbuhannya dibandingkan dengan peningkatan produksi beras.

Gambar 1. Perkembangan Komoditas Beras di Indonesia

\section{PERMINTAAN BERAS (JUTA TON)}

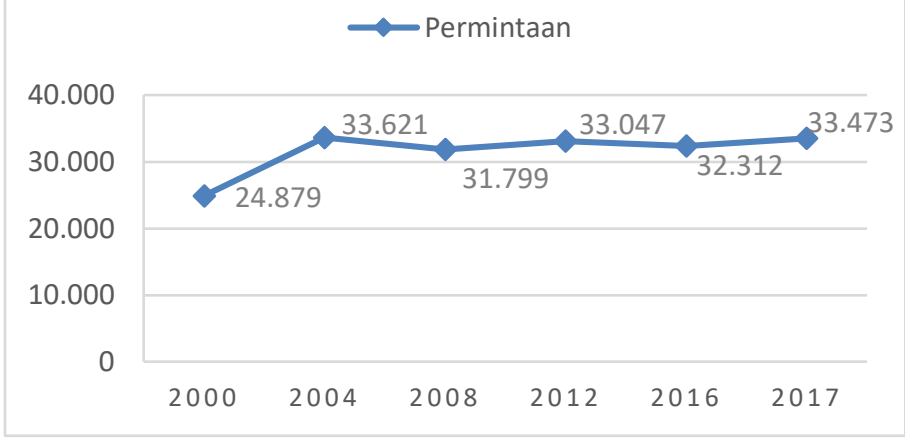

Sumber: Kementerian Pertanian, 2018 (diolah)

Gambar 2. Produksi Beras Indonesia berdasarkan wilayah tahun 2015

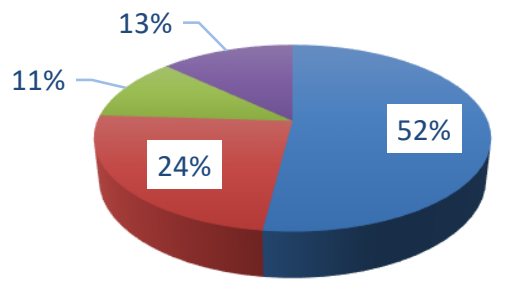

D. Jawa P. Sumatera P. Sulawesi Lainnya

Jika dilihat berdasarkan analisis wilayah, produksi beras terbesar terpusat di Pulau Jawa dengan tingkat kontribusi produksi pada tahun 2015 sebanyak 52 persen dari total produksi nasional, dimana sentra produksi beras terdapat di Provinsi Jawa Timur, Jawa Barat dan Jawa Tengah. Jumlah produksi beras terbesar kedua di Pulau Sumatera dengan tingkat kontibusi hasil produksi beras 24 persen dimana sentra produksi terdapat di Provinsi Sumatera Utara, Lampung dan Sumatera Barat, dan jumlah produksi beras ke tiga terbesar berada di Pulau Sulawesi dengan tingkat kontribusi hasil produksi beras sebanyak 11 persen dimana sentra produksi terdapat di Provinsi Sulawesi Selatan (BPS, 2016).

Indonesia merupakan salah satu negara produsen beras terbesar ketiga di dunia, ironisnya Indonesia masih menjadi negara importir beras karena produksi beras nasional belum mencukupi kebutuhan konsumsi beras dalam negeri. Situasi ini disebabkan karena para petani menggunakan teknik-teknik pertanian yang tidak optimal dan masih tradisional dalam berproduksi. Disisi lain Indonesia memiliki konsumsi beras per kapita terbesar di dunia, dimana konsumsi per kapita beras pada tahun 2017 sekitar 114.6 kg per kapita. Fakta ini menjadi tantangan bagi pengambil kebijakan untuk menjaga stabilitas ketersediaan berasdan keterjangkuan harganya di pasar.

\subsection{Analisis faktor-faktor yang mempengaruhi permintaan beras}

Indonesia

1. Pengaruh variabel bebas secara simultan terhadap permintaan beras

\section{a. Uji F-Statistik}

Berdasarkan kriteria statistik, pada penelitian ini seluruh variabel bebas yang terdiri dari harga beras eceran $\left(\mathrm{X}_{1}\right)$, pendapatan perkapita $\left(\mathrm{X}_{2}\right)$, jumlah penduduk $\left(\mathrm{X}_{3}\right)$, produksi beras $\left(\mathrm{X}_{4}\right)$ dan lag permintaan beras $\left(\mathrm{X}_{5}\right)$ secara simultan berpengaruh signifikan terhadap jumlah permintaan beras untuk konsumsi. Hasil tersebut dibuktikan dengan nilai Probabilitas F-statistic sebesar 0.0000 , nilai ini lebih kecil dari nilai taraf signifikansi sebesar 5 persen.

\section{b. Koefsien Determinasi}

Koefisien determinasi ( $R$ Square) dimaknai sebagai kontribusi yang diberikan variabel bebas $(\mathrm{X})$ dalam menjelaskan variasi variabel terikat $(\mathrm{Y})$ dengan satuan persentase (\%). Berdasarkan hasil output regeresi linier pada tabel 1 , Nilai $R$-Squared sebesar 0.913061 , artinya 91.30 persen variasi jumlah permintaan beras mampu dijelaskan dengan baik oleh variabel bebas, sisanya sebesar 8.70 persen variasi jumlah permintaan beras dijelaskan variabel lain di luar model. Lihat tabel 1.
Tabel 1. Hasil Output Estimasi Persamaan Permintaan Beras

\begin{tabular}{lccc}
\hline Variable & Coefficient & T-Statistic & Prob. \\
\hline $\mathrm{C}$ & $-2.07 \mathrm{E}+10$ & -2.500308 & 0.0196 \\
$\mathrm{HRBE}_{\mathrm{t}}$ & -2589473. & $-3.458694^{*}$ & 0.0020 \\
PPP $_{\mathrm{t}}$ & 444.4005 & $2.746001^{*}$ & 0.0113 \\
JPI $_{\mathrm{t}}$ & 270.2279 & $4.294032^{*}$ & 0.0003 \\
PRODBI $_{\mathrm{t}}$ & -0.459001 & $-2.177886^{*}$ & 0.0395 \\
PMBERAS $_{\mathrm{t}-1}$ & 0.420575 & $2.649046^{*}$ & 0.0141 \\
\hline R-squared & 0.9130 & Prob(F-statistic) & 0.0000 \\
\hline
\end{tabular}

* Kriteria signifikansi pada taraf $\alpha=5$ persen.

Sumber: Output E-Views 9 (diolah)

\section{Pengaruh variabel bebas secara parsial terhadap permintaan beras}

\section{Harga beras eceran}

Berdasarkan hasil penelitian, variabel harga beras eceran memiliki hubungan positif terhadap permintaan beras. Ketika terjadi penurunan tingkat harga, konsumen akan terdorong untuk mengkonsumsi lebih banyak sehingga akhirnya meningkatkan jumlah permintaan. Secara statistik, berdasarkan hasil penelitian menunjukkan harga beras eceran memiliki pengaruh signifakan terhadap jumlah permintaan beras dengan nilai probabilitas sebesar 0.0020 lebih kecil dari taraf signifikansi 5 persen. hasil penelitian ini didukung oleh penelitian (Septiadi, Harianto, \& Suharno, 2016) dan (Asa, 2018) yang menunjukkan bahwa permintaan beras untuk konsumsi dipengaruhi secara signifikan oleh harga beras.

\section{Pendapatan perkapita}

Salah satu indikator kesejahteraan dalam ekonomi ditandai dengan nilai pendapatan perkapita. Berdasarkan hasil penelitian ini, pendapatan perkapita memiliki tanda positif dengan permintaan beras. Secara statistik pendapatan perkapita berpengaruh signifikan terhadap permintaan beras Indonesia. Dibuktikan dengan nilai probabilitas sebesar 0.0113 lebih kecil dari nilai taraf signifikansinya sebesar 5 persen. Hasil penelitian ini sejalan dengan penelitian Sunaryati $d k k$., (2016) berdasarkan hasil analisis uji-t diketahui bahwa variabe pendapatan penduduk berpengaruh signifikan terhadap permintaan beras. Temuan dalam penelitian ini juga sesuai dengan penyataan Samuelson dan William (1999) menyatakan bahwa pendapatan disposable merupakan faktor utama yang mempengaruhi dan menentukan jumlah pengeluaran untuk konsumsi. Penjelasan ini memiliki makna bahwa semakin tinggi pendapatan sesorang maka secara agregat konsumsi barang dan jasa juga meningkat.

\section{Jumlah penduduk}

Berdasarkan analisis statistik menunjukkan bahwa variabel jumlah penduduk berpengaruh signifikan terhadap variabel permintaan beras. Hasil penelitian ini dibuktikan dengan nilai 0.0003 lebih kecil dari nilai taraf signifikansinya sebesar 5 persen.

Hasil penelitian ini sesuai dengan penelitian sebelumnya yang dilakukan Hutauruk (1996) dan Nuryanti (2005) yang menjelaskan bahwa peningkatan jumlah penduduk memiliki pengaruh yang nyata terhadap peningkatan permintaan dan harga beras. Begitu juga dengan penelitian yang dilakuan Mulyana (1998) hasil penelitiannya menyimpulkan bahwa kenaikkan permintaan beras domestik dipengaruhi secara nyata oleh peningkatan jumlah penduduk dan peningkatan pendapatan. Temuan ini penting untuk dijadikan dasar kebijakan lembaga terkait dalam upaya pengendalian penduduk, karena baik dalam jangka pendek maupun jangka panjang permintaan beras sangat responsif terhadap perubahan jumlah penduduk.

Disisi yang lain, pertumbuhan jumlah produksi beras mengalami perlambatan. Menurut Malthus dalam Rusli (1989) mengatakan bahwa pertumbuhan penduduk mengikuti deret hitung, sedangkan pertumbuhan pangan mengikuti deret ukur. Artinya jika tidak ada pengekangan, maka kecenderungan pertumbuhan jumlah manusia akan lebih cepat daripada pertumbuhan produksi bahan pangan. Temuan tersebut mendukung hasil dalam penelitian ini.

\section{Produksi beras}

Berdasarkan hasil penelitian menunjukkan bahwa produksi beras memiliki hubungan dengan tanda negatif dengan permintaannya. Secara statistik variabel produksi beras menunjukkan pengaruh yang signifikan, dibuktikan dengan nilai probabilitas sebesar 0.0395 lebih kecil dari nilai taraf signifikansinya sebesar 5 persen. Temuan ini berbeda dengan teori ekonomi. Salah Salah satu tokoh ekonomi klasik bernama Jean Baptiste Say mempopulerkan hukum J.B.Say's yang berbunyi "supply creates its own demand". Hukum ini memiliki makna bahwa setiap barang dan jasa yang diproduksi akan mencipatakan permintaannya sendiri. Artinya produksi barang dan jasa memiliki hubungan positif dengan permintaan barang dan jasa tersebut. 5. Lag permintaan beras

Berdasarkan analisis statistik menunjukkan bahwa variabel lag permintaan beras Indonesia berpengaruh signifikan terhadap variabel permintaan beras dengan tanda positif. Hasil ini dibuktikan dengan nilai probabilitasnya sebesar 0.0141 lebih kecil dari nilai taraf signifikansinya sebesar 5 persen.

\subsection{Analisis respon permintaan beras Indonesia}

Analisis respon digunakan untuk mengetahui nilai elastisitas dari tiap variabel bebas dalam mempengaruhi variabel terikat. Sehingga dapat diketahui seberapa besar perubahan variabel terikat akibat adanya perubahan variabel bebas. Berdasarkan hasil penelitian ini, nilai elastisitas adalah sebagai berikut; 
Tabel 2. Hasil Analisis Respon Permintaan Beras Indonesia

\begin{tabular}{lcc}
\hline & \multicolumn{2}{c}{ Elastisitas } \\
\cline { 2 - 3 } Variable & $\begin{array}{c}\text { Jangka } \\
\text { Pendek }\end{array}$ & $\begin{array}{c}\text { Jangka } \\
\text { Panjang }\end{array}$ \\
\hline $\mathrm{C}$ & & \\
$\mathrm{HRBE}_{\mathrm{t}}$ & $-0,37$ & $-0,79$ \\
$\mathrm{PPP}_{\mathrm{t}}$ & 0,24 & $-0,18$ \\
$\mathrm{JPI}_{\mathrm{t}}$ & 1,98 & 1,56 \\
PRODBI$_{\mathrm{t}}$ & $-0,55$ & $-0,97$ \\
PMBERAS $_{\mathrm{t}-1}$ & &
\end{tabular}

\section{Harga beras eceran}

Berdsarkan hasil analisis respon pada tabel 2 menunjukkan bahwa respon permintaan beras terhadap harga beras eceran bersifat inelastis. Hal ini dibuktikan dengan nilai elastisitas masing-masing dalam jangka pendek sebesar 0.37 dan dalam jangka panjang sebesar 0.79. Sehingga elastisitas permintaan terhadap harga beras eceran bersifat inelastis $(\mathrm{Ed}<1)$. Temuan ini memiliki makna bahwa permintaan beras tidak responsif terhadap perubahan harga beras eceran baik dalam jangka pendek maupun dalam jangka panjang. Jika harga beras eceran naik sebesar 10 persen, maka akan berdampak kepada penurunan jumlah perminaan beras sebesar 3.7 persen dalam jangka pendek dan sebesar 7.9 persen dalam jangka panjang. Temuan ini menunjukkan bahwa kenaikan harga beras eceran akan menurunkan permintaan beras akan tetapi dengan persentase yang lebih sedikit. Hasil ini sesuai dengan penelitian Ritonga (2004) menjelaskan bahwa elastisitas harga beras yang rendah memiliki makna bahwa upaya dalam mengendalikan harga ternyata memiliki pengaruh yang lemah terhadap permintaan beras. Permintaan beras lebih ditentukan oleh pertumbuhan penduduk dan peningkatan pendapatan daripada perubahan harga. Sejalan dengan Ritonga, menurut Sari (2007) untuk konsumen berpenghasilan rendah, perubahan harga beras tidak terlalu berpengaruh besar dalam jumlah permintaan beras, tapi berpengaruh pada frekuensi pembelian beras dan kualitas beras yang dibeli. Temuan Ritonga tersebut mempertegas komoditi beras adalah komoditi yang bersifat inelastis. Berdasarkan penelitian Ariani et al (2000) meski elastisitas harga beras adalah inelastis, akan tetapi upaya stabilitas harga beras di pasar domestik masih dipandang perlu, karena tingkat partisipasi konsumsi komoditi beras di Indonesia masih sangat tinggi mencapai sekitar 97 persen.

\section{Pendapatan perkapita}

Berdasarkan hasil analisis respon pada tabel 2 menunjukkan bahwa respon permintaan beras terhadap pendapatan perkapita bersifat inelastis. Hal ini dapat dibuktikan dengan melihat nilai elastisitas masing-masing dalam jangka pendek sebesar 0.24 dan dalam jangka panjang sebesar 0.18. Sehingga elastisitas permintaan terhadap pendapatan perkapita bersifat inelastis $(\mathrm{Ed}<1)$. Hasil ini memiliki makna bahwa permintaan beras tidak responsif terhadap perubahan pendapatan perkapita baik dalam jangka pendek maupun dalam jangka panjang. Bahkan nilai elastisitasnya lebih kecil dibandingkan dengan nilai elastisitas dari variabel harga beras eceran. Jika pendapatan perkapita naik sebesar 10 persen, maka akan berdampak kepada penurunan jumlah perminaan beras sebesar 2.4 persen dalam jangka pendek dan sebesar 1.8 persen dalam jangka panjang. Hasil ini menunjukkan bahwa kenaikan pendapatan perkapita penduduk Indonesia akan menaikan permintaan beras akan tetapi dengan prosentase yang jauh lebih sedikit.

\section{Jumlah penduduk Indonesia}

Berdasarkan hasil analisis respon pada tabel 2 menunjukkan bahwa respon permintaan beras terhadap jumlah penduduk Indonesia bersifat elastis, dimana nilai elastisitasnya masing-masing sebesar 1.98 dalam jangka pendek dan sebesar 1.56 dalam jangka panjang. Artinya permintaan beras responsif terhadap perubahan jumlah penduduk. Jika terjadi kenaikan jumlah penduduk sebanyak 10 persen, maka akan mengakibatkan kenaikan permintaan beras sebanyak 19.8 persen dalam jangka pendek dan sebanyak 15.6 persen dalam jangka panjang. Artinya variabel jumlah penduduk merupakan variabel bebas yang paling dominan dalam mempengaruhi permintaan beras Indonesia jika dibandingkan dengan veriabel bebas yang lain karena memiliki elastisitas > 1 (elastis)

\section{Produksi beras}

Berdsarkan hasil analisis respon pada tabel 2 menunjukkan bahwa respon permintaan beras terhadap produksi beras bersifat inelastis. Hal ini dapat dibuktikan berdasar pada hasil analisis respon yang menunjukkan bahwa nilai elastisitas jangka pendek sebesar 0.55 dan elastisitas jangka panjang sebesar 0.97. Artinya permintaan beras tidak responsif terhadap perubahan produksi beras. Jika produksi beras naik sebesar 10 persen, maka akan berdampak pada penurunan jumlah perminaan beras sebesar 0.55 persen dalam jangka pendek dan sebesar 0.97 persen dalam jangka panjang.

\section{Simpulan}

Variabel harga beras eceran domestik (x1), pendapatan perkapita (x2), jumlah penduduk (x3), produksi beras (x4) dan lag permintaan beras Indonesia (x5) berpengaruh nyata terhadap permintaan beras di Indonesia secara simultan. Secara uji pengaruh secara parsial, variabel harga beras eceran domestik (x1), pendapatan perkapita (x2), jumlah penduduk (x3), produksi beras (x4) dan lag permintaan beras Indonesia (x5) berpengaruh nyata terhadap permintaan beras Indonesia. Variabel jumlah penduduk memiliki elastisitas lebih dari satu $(\mathrm{E}>1)$ baik dalam analisis jangka pendek maupun jangka penjang. Sedangkan variabel bebas lainnya memiliki elastisitas kurang dari satu $(\mathrm{E}<1)$ baik dalam anaisis jangka pendek maupun jangka panjang.

\section{Pustaka}

A. Samuelson, William DN. 1999. Mikro Ekonomi. Jakarta: Erlangga.

Anriquez G, Stamoulis K. 2007. Rural Development and Poverty Reduction: is agriculture still the key? Electronic Journal of Agriculture and Development Economics. 4 (1):5-46

Ariani M., Saliem HP, Hastuti S, Wahida, Sawit MH. 2000. Dampak Krisis Ekonomi terhadap Konsumsi Pangan Rumah Tangga. Pusat Penelitian dan Pengembangan Sosial Ekonomi Pertanian, Bogor

Arifin, B. (1997). Distribusi komoditas strategis: Catatan Reflektif. Bisnis\& Ekonomi Politik, Vol 1 (2). Hal 1-8

Asa, A. (2018). Faktor-Faktor yang Mempengaruhi Konsumsi Beras di Desa Babotin Maemina Kecamatan Botin Leobele Kabupaten Malaka. Jurnal Agribisnis Lahan Kering, 3(2502), 55-57. https://doi.org/10.32938/ag.v3i4.324

Badan Pusat Statistik. 2016. Basisdata Terpadu. tersedia di halaman https://www.bps.go.id/site/pilihdata.html

Departemen Pertanian. 2004. Analisis Permintaan dan Produksi Beras di Indonesia 2001- 2004, Proyek Pengembangan Ketersediaan Pangan. Eales.

Gujarati N. Damodar. 2003. Basic Econometric, Fourt Edition. New York: McGraw-Hill.

Hutauruk J. 1996. Analisis Kebijakan Harga Dasar Padi dan Subsidi Pupuk terhadap Permintaan dan Penawaran Beras di Indonesia [Tesis]. Bogor (ID): Institut Pertanian Bogor.

Kementerian Pertanian. 2018. Basis Data Statistik Pertanian. tersedia di http://aplikasi.pertanian.go.id/bdsp/index.asp

Mulyana A. 1998. Keragaan Penawaran dan Permintaan Beras Indonesia dan Prospek Swasembada Menuju Era Perdagangan Bebas Suatu Analisis Simulasi [Disertasi]. Bogor (ID): Institut Pertanian Bogor.

Nuryanti S. 2005. Analisa Keseimbangan Sistem Penawaran dan Permintaan Beras di Indonesia. Jurnal Agro Ekonomi. 23 (1): 71-81

Rahmasuciana, Dioni Yurinda,. dkk. (2015).”Pengaruh Pengadaan Beras dan Operasi Pasar terhadap Harga Beras dalam Negeri”. Jurnal Agro Ekonomi Vol. 26, No. 2.

Ritonga E. 2004. Analisis Keefektifan Kebijakan Harga Dasar Beras [Tesis]. Bogor (ID): Institut Pertanian Bogor.

Rosegrant, M.W, F. Kasryno and N.D. Perez. 1998. Output Response to Prices and Public Investment in Agriculture: Indonesian Food Crops. Journal of Development Economics, Elsevier Holland. 55.

Rusli, Said. 1989. Pengantar Ilmu Kependudukan. Jakarta: LP3ES

Sari, Nina Tama. Analisis Dampak Kenaikan Harga Beras Terhadap Pola Konsumsi Beras Rumahtangga di Cipinang, Jakarta Timur. [Skripsi]. Bogor (ID): Institut Pertanian Bogor.

Septiadi, D., Harianto, H., \& Suharno, S. (2016). Dampak Kebijakan Harga Beras dan Luas Areal Irigasi Terhadap Pengentasan Kemiskinan di Indonesia. $\begin{array}{llll}\text { Jurnal Agribisnis } & \text { Indonesia, } & 4(2), & \end{array}$ https://doi.org/10.29244/jai.2016.4.2.91-106

Sunaryati, R., Studi, P., Fakultas, A., Universitas, P., Raya, P., Douglas, C., \& Douglas, C. (2016). ( Analysis of Demand for Rice in the Province of Central Kalimantan ) Pangan adalah kebutuhan mendasar yang secara fisiologi, psikologis, sosial, maupun manusia untuk mempertahankan tumbuh, paling tidak mengikuti pertumbuhan untuk memenuhi permintaan. 3(2), 99-107. https://doi.org/10.33084/daun.v3i2.151 